Our Nature (2010) 8:34-39

\title{
Avian Diversity of Bhoj Wetland: A Ramsar Site of Central India
}

\author{
V. Vyas*, M. Vishwakarma and N. Dhar \\ Department of Limnology, Barkatullah University, Bhopal-462026, India \\ *E-mail: secvip@yahoo.co.in
}

Received: 11.01.2010, Accepted: 28.08.2010

\begin{abstract}
Wetlands provide habitats for various types of birds in different seasons. The present paper discusses the diversity of water birds in Bhoj Wetland of Bhopal which is a Ramsar site and a thousand year old wetland constructed by Raja Bhoj. The wetland provides variety of habitats to the waterbirds and they occupy these habitats according to their niches. Anatidae was the most dominant family recorded during the study period in the peak winter period whereas the population started declining as the temperature rises in the subsequent months. This indicates that most of the migratory species belong to the family Anatidae comprising ducks. They prefer deep water habitats with submerged vegetation. Looking to the importance of the wetland a study was conducted in the winter season in Bhoj Wetland of Bhopal (Central India) which is a Ramsar site.
\end{abstract}

Key words: Avian diversity, Bhoj wetland, Ramsar

\section{Introduction}

One of the best known functions of wetlands is to provide a habitat for birds. Wetlands are important bird habitats and birds use them for breeding, nesting, and rearing young ones. Birds also use wetlands as a source of drinking water and for feeding, resting, shelter, and social interactions (Stewart, 2007).

Looking to the urgent need to conserve the wetlands as waterfowl habitats an international treaty was signed which is called Ramsar Convention. The official name of the treaty, The Convention on Wetlands of International Importance especially as Waterfowl Habitat, reflects the original emphasis upon the conservation and wise use of wetlands primarily as habitat for water birds. Over the years, however, the Convention has broadened its scope of implementation to cover all aspects of wetland conservation and wise use, recognizing wetlands as ecosystems that are extremely important for biodiversity conservation and for the well-being of human communities, thus fulfilling the full scope of the Convention text.

Bhoj wetland of Bhopal is a Ramsar site and supports a rich biodiversity including birds. The present paper describes the diversity of avian fauna of Bhoj Wetland of Bhopal.

\section{Materials and Methods}

The Bhoj Wetland of Bhopal is a huge reservoir (Figure 1), covering an area of about $38 \mathrm{~km}^{2}$. Its catchment area is about $370 \mathrm{~km}^{2}$. The lake is east westerly elongated with irregular margins. The old city is situated on its eastern and northern 
banks. Raw sewage or nearby slums find its way into the lake through various sewage channels. On its Southern side "Van Vihar National Park" and "Museum of Man" are situated on forested slopes of Shamla Hills. On the western bank, land is used for agricultural practices. Fertilizer and pesticide residues find their way into the lake from this side. Most of the lake is very shallow and its shallower portion is infested by a thick growth of macrophytes. The morphometric features of the lake are given in table 1 . The lake has been designated as Ramsar site alongwith its twin lower lake as Bhoj Wetland. The lake is a source of drinking water to some part of old city of Bhopal. It is also used for fisheries, Trapa culture and other domestic purposes by the local residents. The lake also supports a rich biodiversity and provide habitat for wildlife including migratory birds.

The lake has been studied for many limnological and biodiversity aspects but very little have been done on ecology and biodiversity of migratory birds which is an important aspect of wetland ecology. Vyas (1992) has conducted a survey on wetland birds of upper lake in relation to habitats available to migratory birds.

Study of avifaunal diversity of Upper lake was conducted between December, 2007 and June, 2008 for three times. Monthly observations were made during the study but they were clubbed into three observations for further analysis. Birds were observed within the transect of $300 \mathrm{~m}$. Binoculars of $10 \times 50$ were used for observations. The field book of Ali and Ripley (1986), Ali (1996) were used to identify bird species.

\section{Results and discussion}

During December, 2007, 43 species were recorded in the upper lake of Bhopal belonging to 14 families and 8 orders. Family Anatidae was found to be the most dominant family represented by ten species followed by family Ardiedae represented by 8 species. Kumar (2006) recorded Ardidae to be the most dominant family in Bharatpuzha river basin in Kerala and Kurup (1991) attributed it to the larger mudflat areas which attract shorebirds in large numbers. Surana (2007) recorded Anatidae to be most dominant family with 12 species and Ardidae with 9 species in Chimdi lake of Nepal. Rathore and Sharma (1999) also reported Anatidae to be dominating family with 12 species in Sarsai Nawar in UP. Vijayan (1988) also reported 17 species of Anatidae in Bharatpur Wetlands. There was a gradual decline in species richness in the lake as the weather condition changes from colder to warmer. 40 species were recorded during March 08 belonging to 14 families and 8 orders. Anatidae was the most dominant family contributing 12 species during this month also. Ardidae was the second dominant family contributing 6 species in the month of March. This is the time when migratory species start migrating back.

A sharp decline was recorded during June leaving only 25 species of water birds in the lake belonging to 12 families and 8 orders. Anatidae family which was the most dominant family during winter period was represented by only two species. This indicates that most of the wintering water birds belong to Anatidae family. Vijayan (1988) while working on Bharatpur wetland also recorded similar observations. Members of Anatidae family were found to dominate among the winter migratory 


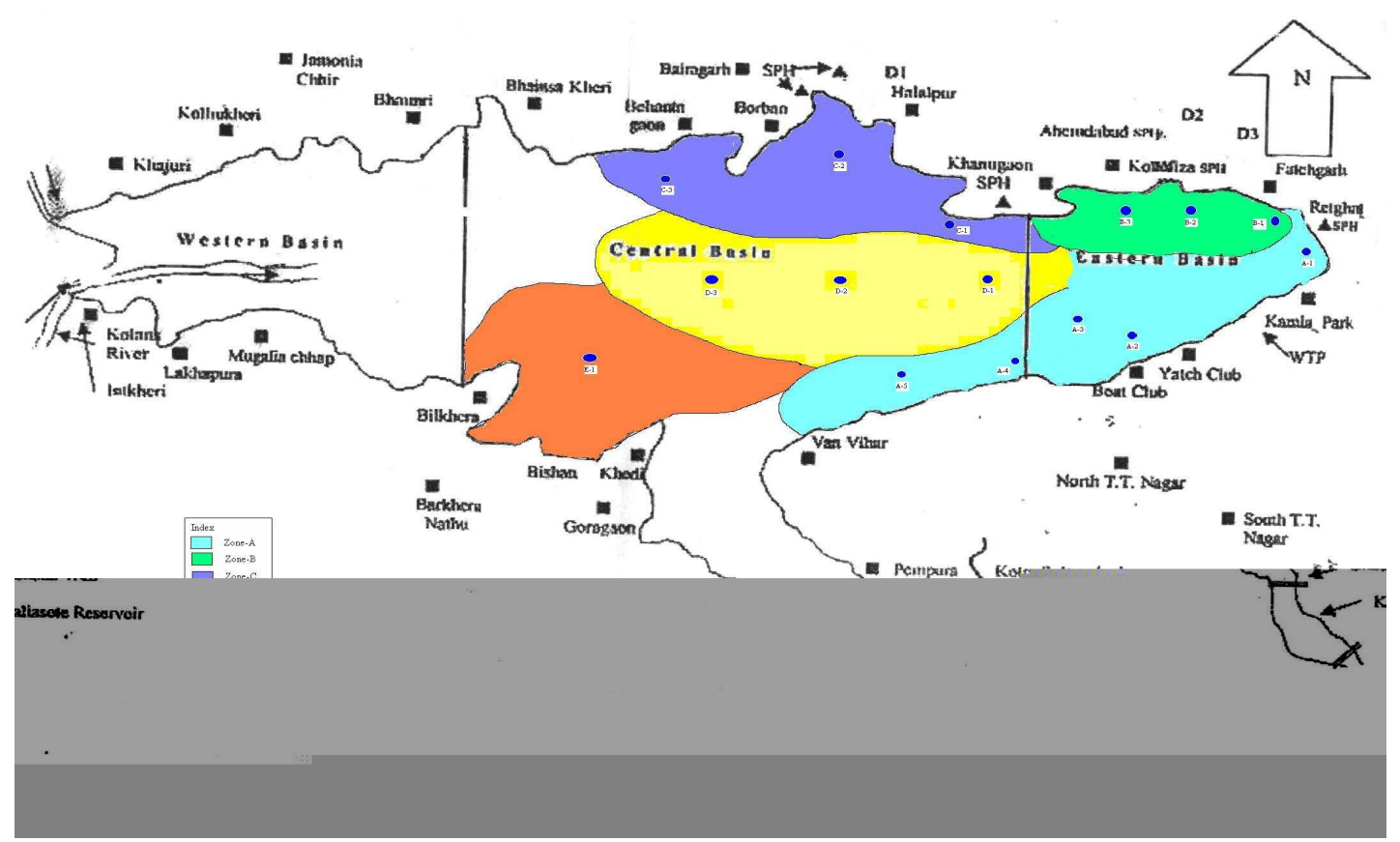

Figure 1. Map of Bhoj wetland (Upper lake) of Bhopal.

Table 1. Morphometric features of Bhoj wetland (Upper lake ) of Bhopal

\begin{tabular}{ll}
\hline Feature & Unit \\
\hline Catchment area & $362 \mathrm{sq} \mathrm{km}$ \\
Submerged area & 30.72 \\
Maximum length & $12.50 \mathrm{~km}$ \\
Maximum width & $5 \mathrm{~km}$ \\
Maximum area & $32 \mathrm{sq} \mathrm{km}$ \\
Minimum area & $12 \mathrm{sq} \mathrm{km}$ \\
Maximum shoreline & $40.590 \mathrm{~km}$ \\
Maximum depth & $8.8 \mathrm{~m}$ \\
Mean depth & $3.17 \mathrm{~m}$ \\
Maximum water level MSL & $508.65 \mathrm{~m}$ \\
Dead storage level MSL & $503.65 \mathrm{M}$ \\
River bed level MSLA & $499.39 \mathrm{M}$ \\
Volume & $101540400 \mathrm{~m}^{3}$ \\
\hline
\end{tabular}

Table 2. List of birds recorded during the present study.

\begin{tabular}{lllll}
\hline SN & Zoological Name & Common Name & Scientific Name & \\
\hline \multirow{2}{*}{$\begin{array}{l}\text { Order } \\
1\end{array}$} & Podicipediformes & & Podiaps ruficollis & \\
\hline & Family- Podicipitidae & Little Grebe & Contd....
\end{tabular}


V. Vyas, M. Vishwakarma and N. Dhar/ Our Nature (2010) 8: 34-39 Table 2-Contd....

\begin{tabular}{|c|c|c|c|}
\hline 2 & Family- Phalacrocoracidae & Large Cormorant & Phalacrocorax carbo \\
\hline 3 & & Indian Cormorant & Phalacrocorax fuscicollis \\
\hline 4 & & Little Cormorant & Phalacrocorax niger \\
\hline 5 & & Darter & Anhinga rufa \\
\hline Order & Ciconiformes & & \\
\hline 6 & Family- Ardeidae & Grey Heron & Ardea cinerea \\
\hline 7 & & Purple Heron & Ardea purpurea \\
\hline 8 & & Pond Heron & Ardeola grayii \\
\hline 9 & & Large Egret & Ardea alba \\
\hline 10 & & Little Egret & Egretta garzetta \\
\hline 11 & & Median Egret & Egretta intermedia \\
\hline 12 & & Cattle Egret & Bubulcus ibis \\
\hline 13 & Family- Ciconiidae & Painted Stork & Mycteria leucocephala \\
\hline Order & Anseriformes & & \\
\hline 14 & Family- Anatidae & Ruddy Shelduck & Tadorna ferruginea \\
\hline 15 & & Spotbill Duck & Anas poecilorhyncha \\
\hline 16 & & Gadwall & Anas strepera \\
\hline 17 & & Eurasian Wigeon & Anas penelope \\
\hline 18 & & Mallard & Anas platyrhynchos \\
\hline 19 & & Northern Shoveler & Anas clypeata \\
\hline 20 & & Northern Pintail & Anas acuta \\
\hline 21 & & Common Pochard & Aythya ferina \\
\hline 22 & & Comb Duck & Sarkidiornis melonotos \\
\hline 23 & & Red crested Pochard & Netta rufina \\
\hline Order & Gruiformes & & \\
\hline 24 & Family- Rallidae & Whitebreasted Waterhen & Amaurornis phoenicurus \\
\hline 25 & & Common Moorhen & Gallinula chloropus \\
\hline 26 & & Purple Moorhen & Porphyrio porphyrio \\
\hline 27 & & Coot & Fulica atra \\
\hline 28 & Family- Gruidac & Sarus Cranes & Grus antigone \\
\hline Order & Charadricformes & & \\
\hline 29 & Family - Jacaniidac & Bronze-Winged Jacana & Metapidius Indicus \\
\hline 30 & & Pheasant-tailed Jacana & Hydrophasianus chlrugus \\
\hline 31 & Family-Charadriidae & Red-wattled Lapwing & vanellus indicus \\
\hline 32 & & Little ringed Plover & Charadrius dubius \\
\hline 33 & & Common Greenshank & Tringa nebularia \\
\hline
\end{tabular}


V. Vyas, M. Vishwakarma and N. Dhar/ Our Nature (2010) 8: 34-39

Table 2-Contd....

\begin{tabular}{|c|c|c|c|}
\hline 34 & & Common Redshank & Tringa totanus \\
\hline 35 & Family- Recurvirostrisae & Black-winged stilt & Himantopus himantopus \\
\hline 36 & Family- Laridae & River Tern & Sterna aurautia \\
\hline 37 & Family- Rostratulidae & Painted Snipe & Rostratula benghalensis \\
\hline Order & Coraciiformes & & \\
\hline 38 & Family- Alcedinidae & Whitebreasted kingfisher & Halcyon smyrensis \\
\hline 39 & & Small blue kingfisher & Alcedo atthis \\
\hline 40 & & Pied Kingfisher & Ceryle rudis \\
\hline Order & Passeriformes & & \\
\hline 41 & Family- Motacillidae & Large pied wagtail & Motacilla maderospaternsis \\
\hline 42 & & Grey wagtail & Motacilla cinerea \\
\hline 43 & & Yellow wagtail & \\
\hline
\end{tabular}

birds. Their monthly occurrence pattern clearly indicates that these birds found between October and March. Coot was the only dominant migratory bird belonging to family Ralidae which could not be recorded after March in the Upper lake. However, family Ardidae became the most dominating family represented by 7 species mostly Egrets and Herons registering there presence throughout the year. Vijayan (1987, 1988) recorded increase in egrets population during monsoon period due to their breeding season.

The above observations indicate that the lake supports atleast 12 migratory species of waterbirds and most of them are ducks feeding and foraging in open water zone. Rathore and Sharma (1999) indicate that most of the members of family Anatidae are herbivore in nature and depend on aquatic flora. They dive upto the depth of $3 \mathrm{~m}$ for feeding. Hence a habitat of open water with submerged vegetation is the most suitable habitat for migratory birds. It is worth mentioning here that such habitats should be mapped in Upper lake and attempts should be made to keep them free from human interference.

\section{Acknowledgements}

Through this publication, the main author (VV) wants to pay his tribute to Late Dr. KK Tiwari, Ex-Director, Zoological Survey of India and Former Vice-Chancellor of Jiwaji University, Gwalior for the encouragement and guidance extended by him to study birds. Authors are thankful to Prof. P. Shrivastava, Dean, Faculty of Life Sciences, Barkatullah University, Bhopal for constant encouragement and lab and field facilities.

\section{References}

Ali, S. 1996. The book of Indian birds. $11^{\text {th }}$ Edition, Bombay Natural History Society and Oxford University Press, Bombay.

Ali, S. and S.D. Ripley 1983. Hand book of the birds of India and Pakistan. Compact ed., Oxford University Press, New Delhi.

Kumar, A.B. 2006. A checklist of avifauna of the Bharathapuzha river basin, Kerala. Zoos' Print 21(8): 2350-2355.

Kurup, D.N. 1991. Migrant shore birds in estuarine 
V. Vyas, M. Vishwakarma and N. Dhar/ Our Nature (2010) 8: 34-39

habitats with special reference to Kadalundi and Bharathapuzha estuaries. In Proceedings of the third Kerala Science Congress, Feb-March, 1991, Kozhikode. pp. 31-32.

Rathore and Sharma 1999. Avifauna of a lake in district Etawah, Uttar Pradesh, India. Zoos' Print 15(6): 275-278.

Steward, R.E. Jr. 2007. Technical aspects of wetlands: Wetlands as bird habitat. United States Geological Survey Water Supply Paper. pp. 24-25.
Surana, R. 2007. Avian diversity during rehabilitation stage of Chimdi lake, Sunsari, Nepal. Our Nature 5(1): 75-80. Vijayan, V.S. 1988. Ecology of Keoladeo National Park. Annual Report.

Vyas, V. 1992. Waterfowl community of Bhoj Wetland of Bhopal with reference to its management and conservation. In Environment and Biodegradation (Ed. V.P. Agrawal). pp. 155-162. 